
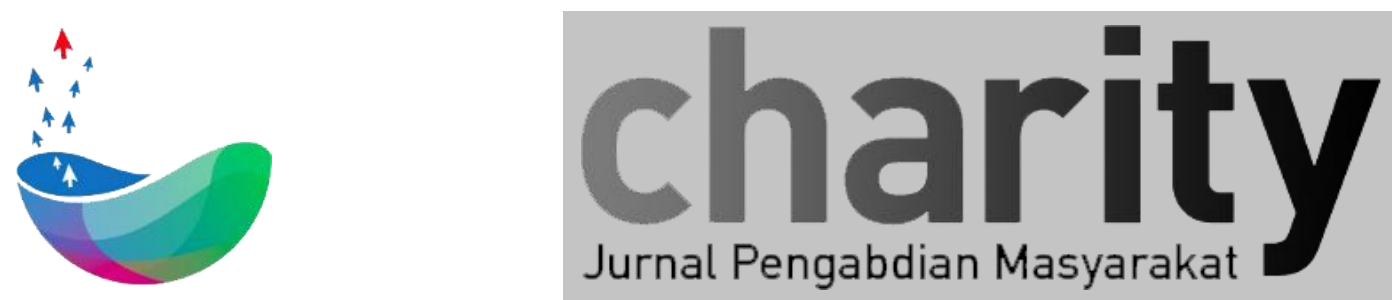

\title{
Digitalisasi Pelayanan Posyandu Melalui Sistem Informasi Posyandu Berbasis Website di Posyandu Anyelir RW 09 Kelurahan Burangrang Kecamatan Lengkong Kota Bandung
}

Tatang Mulyana ${ }^{1}$, Nopendri ${ }^{1}$, Seno Adi Putra ${ }^{2}$, Tien Fabrianti Kusumasari ${ }^{2}$, Hanif Fakhrurroja ${ }^{2}$, Setyorini ${ }^{3}$, Didit Adytia $^{4}$, Widianto Soekarnen ${ }^{5}$, Derry Destian ${ }^{5}$

${ }^{1}$ Teknik Industri, Fakultas Rekayasa Industri, Universitas Telkom

${ }^{2}$ Sistem Informasi, Fakultas Rekayasa Industri, Universitas Telkom

Teknik Informatika, Fakultas Informatika, Universitas Telkom

${ }^{4}$ Ilmu Komputasi, Fakultas Informatika, Universitas Telkom

PT. Mahawangga Winaya Indonesia

* tatangmulyana@telkomuniversity.ac.id, nopendri@telkomuniversity.ac.id, adiputra@telkomuniversity.ac.id, tienkusumasari@telkomuniversity.ac.id, haniff@telkomuniversity.ac.id, setyorini@telkomuniversity.ac.id, adytia@telkomuniversity.ac.id,widhie@ rumahsolusi.co.id, derrydestian@gmail.com

\section{INFO ARTIKEL}

Diterima 07 Februari 2021

Direvisi 04 Agustus 2021

Disetujui 07 Desember 2021

Tersedia Online 04 Februari 2022

\begin{abstract}
ABSTRAK
Posyandu adalah wadah pemberdayaan masyarakat yang diprakarsai oleh masyarakat dan dikelola oleh masyarakat bersama Pemerintah Desa/Kelurahan untuk memberikan kemudahan memperoleh pelayanan kesehatan masyarakat. Banyaknya sistem pelaporan dari Posyandu terkadang menjadi data yang tidak dianalisa secara baik. Hal ini dikarenakan rekapitulasi dan pengumpulan datanya terkadang tidak tepat waktu. Salah satu upaya yang dapat dilakukan untuk memperbaiki hal tersebut adalah diwujudkan melalui sistem teknologi informasi. Sistem ini, dikenal dengan istilah digitalisasi, membantu analisa dari data secara cepat sehingga petugas kesehatan dimudahkan dalam melakukan pekerjaannya. Pengabdian Masyarakat yang dilakukan ini bekerjasama dengan PT Mahawangga Winaya Indonesia melakukan digitalisasi pengisian data kader posyandu dan pengumpulan data bayi dan balita. Pengabdian ini terdiri dari tiga kegiatan utama yang berurutan, yaitu pembuatan program, pengujian, dan pelatihan. Kegiatan pembuatan program dan pengujian sudah dapat dilaksanakan, namun untuk kegiatan selanjutnya, yaitu berupa kegiatan pelatihan belum dapat dilaksanakan.
\end{abstract}

Keyword: Digitalisasi, pelayanan, posyandu, sistem, informasi

Korespondensi:

Direktorat Penelitian dan Pengabdian Masyarakat, Universitas Telkom

J1. Telekomunikasi No. 1, Terusan Buah Batu, Bandung, 40257

Indonesia

E-mail : ppm@telkomuniversity.ac.id

ORCID ID:

Penulis Pertama: Tatang Mulyana

https://doi.org/xxx

Paper_reg_number xxx (C) The Authors. Published by Directorate of Research and Community Service, Telkom

University.

This is an open access article under the $\mathrm{xxx}$ license (https://creativecommons.org/licenses/xxx) 


\section{Latar Belakang}

Pos Pelayanan Terpadu yang selanjutnya disebut Posyandu adalah salah satu bentuk upaya kesehatan bersumber daya masyarakat (UKBM) yang dikelola dan diselenggarakan dari, oleh, untuk dan bersama masyarakat dalam penyelenggaraan pembangunan kesehatan, guna memberdayakan masyarakat dan memberikan kemudahan kepada masyarakat dalam memperoleh pelayanan kesehatan dasar untuk mempercepat penurunan angka kematian ibu dan bayi [1]. Posyandu merupakan wadah pemberdayaan masyarakat yang dibentuk melalui musyawarah mufakat desa/kelurahan yang dikelola oleh pengelola Posyandu.

Upaya peningkatan peran dan fungsi Posyandu bukan semata-mata tanggungjawab pemerintah saja, namun semua komponen yang ada di masyarakat dalam hal ini aparat pemerintahan, tenaga kesehatan, tokoh masyarakat, tokoh agama dan sukarelawan. Menurut Perbup Bandung No. 32 Tahun 2016 tetang revitalisasi posyandu [2], revitalisasi Posyandu adalah pengintegrasian layanan sosial dasar di Posyandu untuk meningkatkan fungsi dan kinerja Posyandu. Pengelola Posyandu adalah unsur masyarakat, lembaga kemasyarakatan, organisasi kemasyarakatan, lembaga swadaya masyarakat, lembaga mitra pemerintah, dan dunia usaha yang dipilih, bersedia, mampu, dan memiliki waktu dan kepedulian terhadap pelayanan sosial dasar masyarakat di Posyandu. Kader Posyandu yang selanjutnya disebut kader adalah anggota masyarakat yang bersedia, mampu dan memiliki waktu untuk menyelenggarakan kegiatan Posyandu secara sukarela. Kader posyandu aktif adalah kader yang rutin melaksanakan kegiatan Posyandu dan menjalankan tugas dan perannya sebagai Kader. Kader Posyandu terlatih adalah Kader Posyandu yang telah mengikuti pelatihan terkait bidang layanan Posyandu.

Inovasi pelayanan publik berperan sebagai sarana percepatan peningkatan kualitas publik. Oleh karena itu kebaruan inovasi, manfaat, dan keberlanjutan yang teruji dari suatu instansi atau unit kerja diharapkan dapat menjadi praktik terbaik untuk direplikasi oleh instansi atau unit kerja yang lain. Dengan cara demikian kita mengharapkan pelayanan publik di Indonesia menjadi semakin maju [3]. Salah satu inovasi pelayanan public oleh posyandu diantaranya adalah pengukuran berat balita dibantu oleh alat timbang digital dengan resolusi yang diperlukan. Data bisa langsung tercatat di perangkat genggam. Dengan bantuan Open Data Kit Collect data bisa disimpan sebelum diunggah ke Open Data Kit Aggregate server setelah ada koneksi internet. Perangkat kelurahan diharapkan bisa mendesain borang pencatatan dan menganalisa data hasil pencatatan Open Data Kit [4].

PT. Mahawangga Winaya Indonesia adalah sebuah badan usaha yang didirikan sebagai perusahaan startup dengan misi untuk menghasilkan kapasitas di semua bidang sosial, khususnya di bidang pendidikan dan peningkatan kapasitas sosial. Salah satu aktivitas utama pada unit ini adalah di Bidang IT yang salah satu fungsinya untuk menghasilkan output jasa 
berupa IT solutions. PT. Mahawangga Winaya Indonesia memiliki beberapa proyek berbentuk IT solutions, salah satu di antaranya adalah sistem informasi pelayanan Posyandu di Kota Bandung yang berbasis aplikasi web.

\section{Studi Pustaka}

Posyandu memiliki peranan penting dalam meningkatan kualitas kesehatan ibu dan anak melalui proses pelayanan kesehatan, dan penelitian yang mengkaji tentang peran Posyandu sebagai pusat informasi kesehatan ibu dan anak telah dilakukan [5]. Kajian ini menggunakan metode kualitatif dan teknik pengumpulan data melalui wawancara, observasi, Focus Group Discussion, dan studi pustaka. Responden dalam penelitian ini adalah para kader posyandu, para kader PKK Desa, tenaga medis, dan para anggota posyandu. Hasil penelitian menunjukkan bahwa persepsi masyarakat terhadap program Posyandu cukup postif. Posyandu memiliki peranan penting dalam meningkatan kualitas kesehatan ibu dan anak melalui proses pelayanan kesehatan, dan Posyandu sudah menjadi pusat informasi kesehatan masyarakat.

Posyandu banyak memiliki manfaat bagi masyarakat, dimana masyarakat mendapat kemudahan dalam memperoleh informasi dari pelayanan kesehatan bagi ibu,bayi, dan anak balita. Pertumbuhan bayi dan balita juga dapat terpantau sehingga tidak mengalami menderita gizi buruk, bayi dan balita mendapatkan vitamin A, bayi dapat memperoleh imunisasi yang lengkap. Penelitian untuk mengetahui apa yang menjadi faktor penyebab penurunan kunjungan bayi dan balita ke Posyandu telah dilakukan oleh [6]. Desain penelitiannya menggunakan kualitatif fenomenologi. Partisipan dalam penelitian ini adalah ibu yang memiliki anak usia 1-59 bulan berdomisili di wilayah kerja Puskesmas Langsat Pekanbaru yang berjumlah 9 orang. Dari hasil penelitian diperoleh pengetahuan yang kurang, sikap ibu yang negatif, keterbatasan waktu, pekerjaan, informasi tentang Posyandu, kualitas pelayanan kesehatan, tidak ada dukungan keluarga, dan komposisi vaksin dapat mempengaruhi penurunan kunjungan bayi dan balita ke Posyandu.

Penelitian untuk mengetahui faktor-faktor yang mendukung keberhasilan merevitalisasi Posyandu telah dilakukan oleh [7]. Metode penelitian yang digunakan yaitu metode penelitian kualitatif dengan teknik pengumpulan data melalui observasi/pengamatan, wawancara dan penelaahan dokumen. Selanjutnya data yang bersumber dari Pokjanal Kota Banjar dan Kader Posyandu yang ada di Kota Banjar dianalisis dengan tahapan : mereduksi data, memaparkan data dan menarik kesimpulan. Adapun hasil penelitian menunjukkan bahwa faktor-faktor yang mempengaruhi keberhasilan Kota Banjar dalam merevitalisasi Posyandu antara lain : 1). Komitmen Walikota, 2). SDM pelaksana, 3). Anggaran, 4) Partisipasi Masyarakat. Oleh karena itu, Selain para pemangku kepentingan perlu memahami dan mengaplikasikan pedoman penyelenggaraan revitalisasi posyandu, keberhasilan Kota Banjar 
ini dapat menginspirasi Kabupaten/Kota lainnya yang ada di Indonesia untuk melakukan berbagai inovasi.

Sangat disadari bahwa kuantitas data saja tidak cukup, diperlukan data yang berkualitas, karena data yang rendah mutunya berakibat pada pengambilan kebijakan dan intervensi program kesehatan yang keliru. Dukungan data dan informasi kesehatan yang akurat, tepat, dan cepat sangat menentukan dalam pengambilan keputusan dan menetapkan arah kebijakan serta strategi pembangunan kesehatan yang tepat. Untuk meningkatkan kualitas data maka harus dibangun sistem pemantauan kualitas data, sehingga data rutin menjadi data yang akurat, valid, reliable (handal) up to date dan terjaga kerahasiahannya, dan selain itu untuk menjamin kevalidan data dan kesamaan dalam menerima informasi perlu dipikirkan konsep satu data sehingga setiap tahapan pemerintahan memiliki data dan informasi yang sama. Syrat untuk menjamin terwujudnya satu data diperlukan minimal 3 syarat yaitu sistem pelaporan harus dalam satu portal data, Standar data yang sama dan meta data yang sama, sehingga pertukaran dan integrasi data dapat dilakukan dengan mudah [8].

Pembuatan aplikasi web meliputi pembuatan analisis kebutuhan pengguna dan sistem, Use Case Diagram, Entity Relationship Diagram, mockup serta pemrogramannya [9]. Beberapa artikel jurnal berkaitan dengan sistem informasi pelayanan posyandu berbasis website, diantaranya adalah [10], [11], [12], dan [13]. Sementara artikel prosiding diantaranya adalah [14] dan [15].

\section{Metode Pelaksanaan}

Kegiatan Abdimas ini dilakukan melalui tiga tahapan, yaitu pembuatan program, pengujian, dan pelatihan. Pembuatan program meliputi perencanaan kegiatan, survey lokasi kegiatan, penelaahan digitalisasi pengisian data, dan pembuatan perangkat lunak. Pengujian program dilakukan untuk pengisian data posyandu, data kader, dan register bayi dan balita di posyandu tersebut. Kegiatan pelatihan meliputi pembuatan panduan pelatihan, dan pembuatan video pelatihan. Gambar 1 menampilkan gambaran Iptek yang ditransfer ke mitra. 


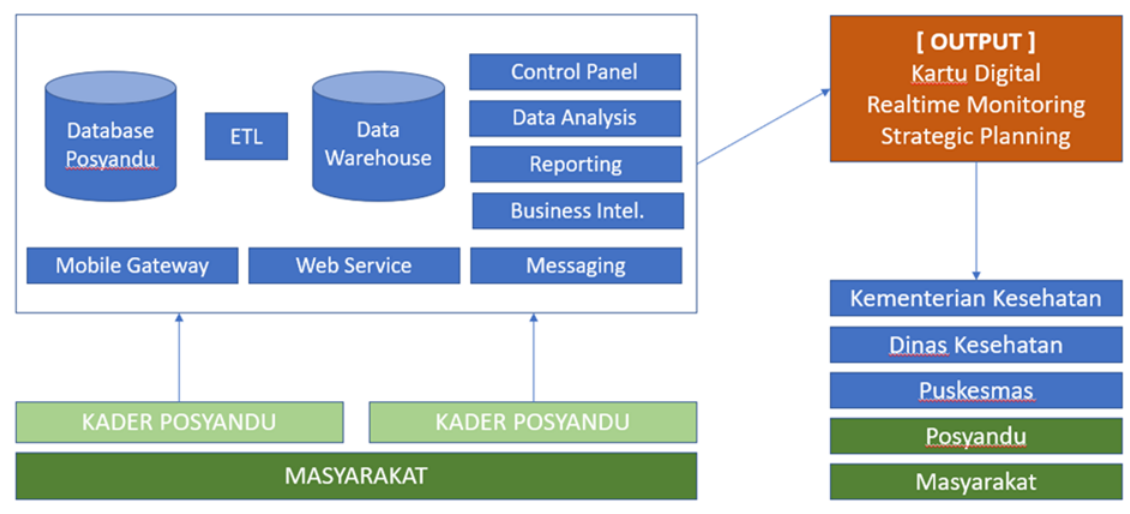

Gambar 1. Gambaran IPTEK yang ditransfer ke mitra.

Masyarakat yang dilayani oleh Kader Posyandu memberikan data-data untuk diinput oleh kader melalui aplikasi pelaporan Posyandu. Data tersebut dikirimkan melalui Mobile Gateway, Web service dan Messaging dan dikumpulkan dalam database Posyandu untuk kemudian dilakukan proses ETL (Extract, Transform, Load) sebagai data di Datawarehouse. Dari Data Warehouse dapat di generate Reporting, Data Analysis, Business Intelligence, dll. Output yang didapat untuk stakeholder system ini adalah, Kartu Digital untuk masyarakat, Realtime monitoring dan strategic planning untuk Dinas dan Kementerian Kesehatan.

\subsection{Persiapan dengan Mitra Pengabdian Masyarakat}

Pencarian data dan informasi tentang mitra pengabdian masyarakat dilakukan dengan media Whatsapp dan tatap muka yang diminimalisir dikarenakan pandemi Covid 19. Diskusi secara daring dilakukan untuk mendapatkan informasi mengenai masyarakat sasar serta penyusunan materi untuk pengabdian Masyarakat (Gambar 2). Rancangan kegiatan dibuat dalam bentuk proposal dan didiskusikan kembali kepada mitra. Proses pembuatan proposal meliputi profil mitra, tujuan serta materi-materi yang akan disampaikan oleh tim kepada masyarakat sasar. Finalisasi proposal diajukan ke pihak PPM Universitas Telkom untuk diproses lebih lanjut. Pada tahap penyelesaian administrasi perijinan, dilakukan legalitas kegiatan dengan penandatanganan surat kesediaan menjadi mitra pelaksanaan kegiatan pengabdian pada Masyarakat (Gambar 3). Kemudian proses selanjutnya yaitu dilakukan finalisasi proposal untuk diajukan ke pihak PPM Telkom University. Gambar 4 menampilkan Pertemuan antara Mitra dari PT Mahwangga Winaya Indonesia dan Tim Pengabdian Masyarakat untuk merancang seluruh kegiatan yang diperlukan telah dilaksanakan di RM Ponyo Malabar, Jalan Malabar No. 60 Kota Bandung. 


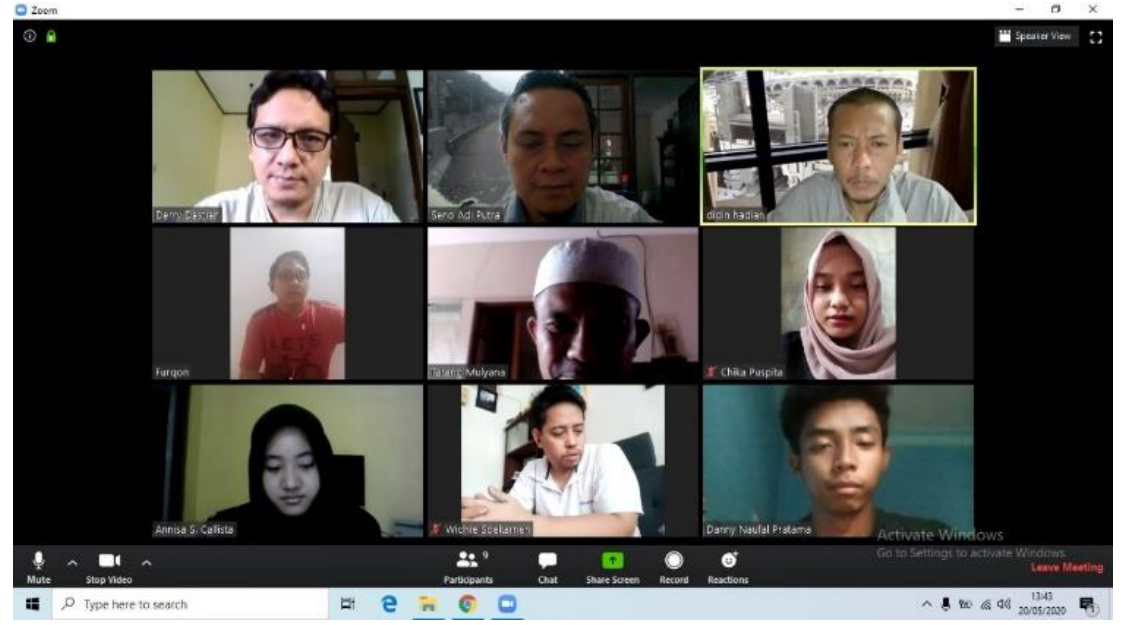

Gambar 2. Pertemuan secara online antara ketua tim pengabdian masyarakat dan mitra disertai mahasiswa yang akan terlibat kegiatan pengabdian.

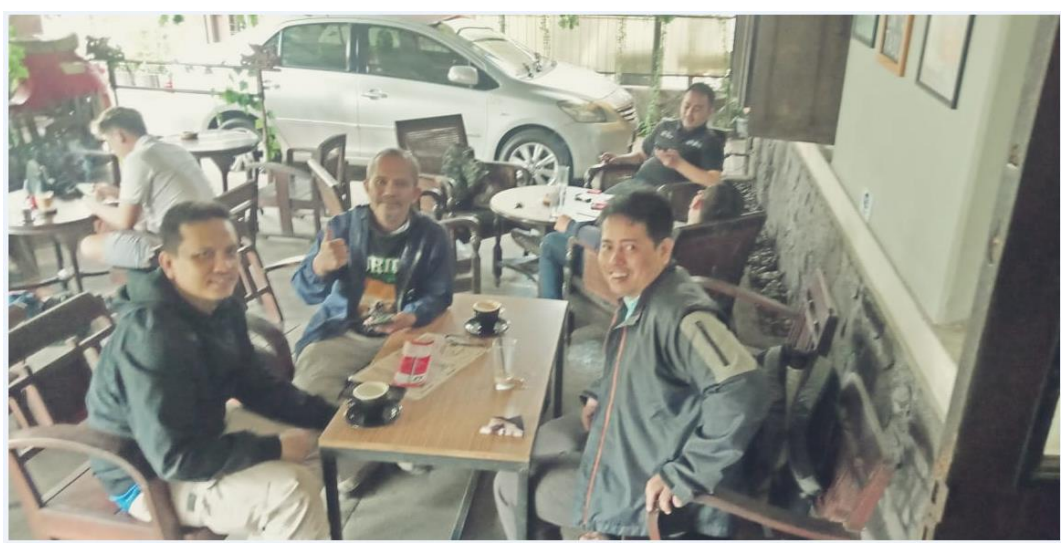

Gambar 3. Pertemuan secara tatap mata antara Ketua Tim Pengabdian Masyarakat dengan Mitra dari PT Mahawangga Winaya Indonesia di Jalan Wayang No. 12 Kota Bandung.

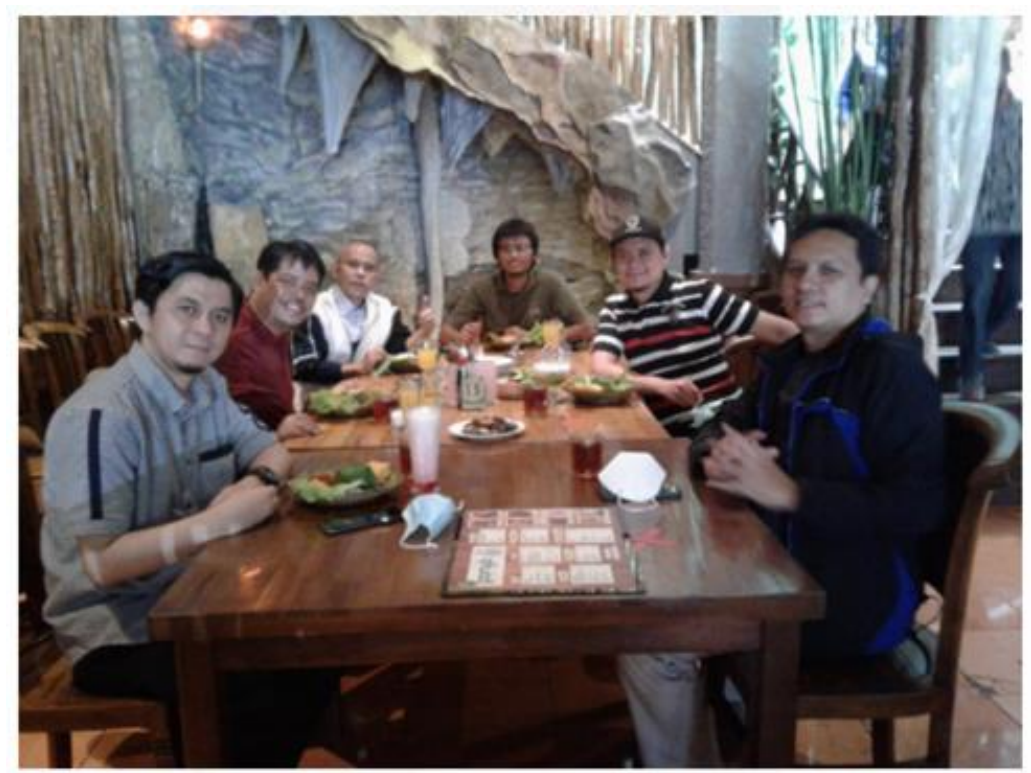


Gambar 4. Pertemuan Tim Pengabdian dan Mitra membahas rencana kegiatan pengabdian di RM Ponyo Malabar, Jalan Malabar No. 60 Kota Bandung.

\subsection{Lokasi Kegiatan Pengabdian Masyarakat}

Lokasi kegiatan pengabdian Masyarakat ini ditetapkan bersama antara Tim Pelaksana dan Mitra Pengabdian Masyarakat, yaitu Posyandu Anyelir RW 09 Kelurahan Burangrang Kecamatan Lengkong Kota Bandung, yang berada di kawasan PHC Talaga Bodas (UPT Puskesmas Talaga Bodas). Lokasi kegiatan ditampilkan pada Gambar 5.

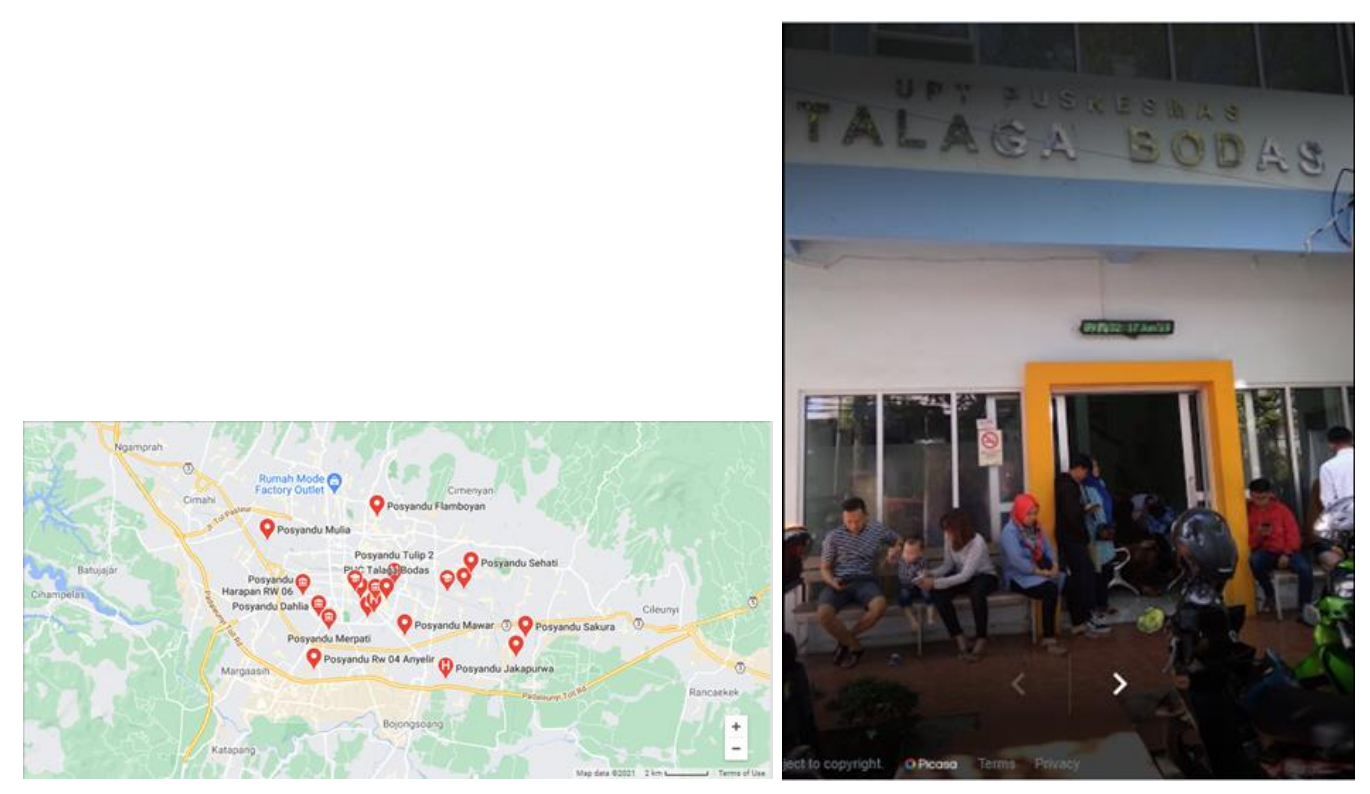

Gambar 5. Lokasi kegiatan pengabdian masyarakat

\section{Analisa \& Hasil Kegiatan}

Berikut ini, Gambar 6 sampai Gambar 11, menampilkan hasil dari program digitalisasi yang berhasil dibuat untuk menampilkan data posyandu, data kader, register bayi dan balita, sebagai contoh untuk kegiatan pengujian. 


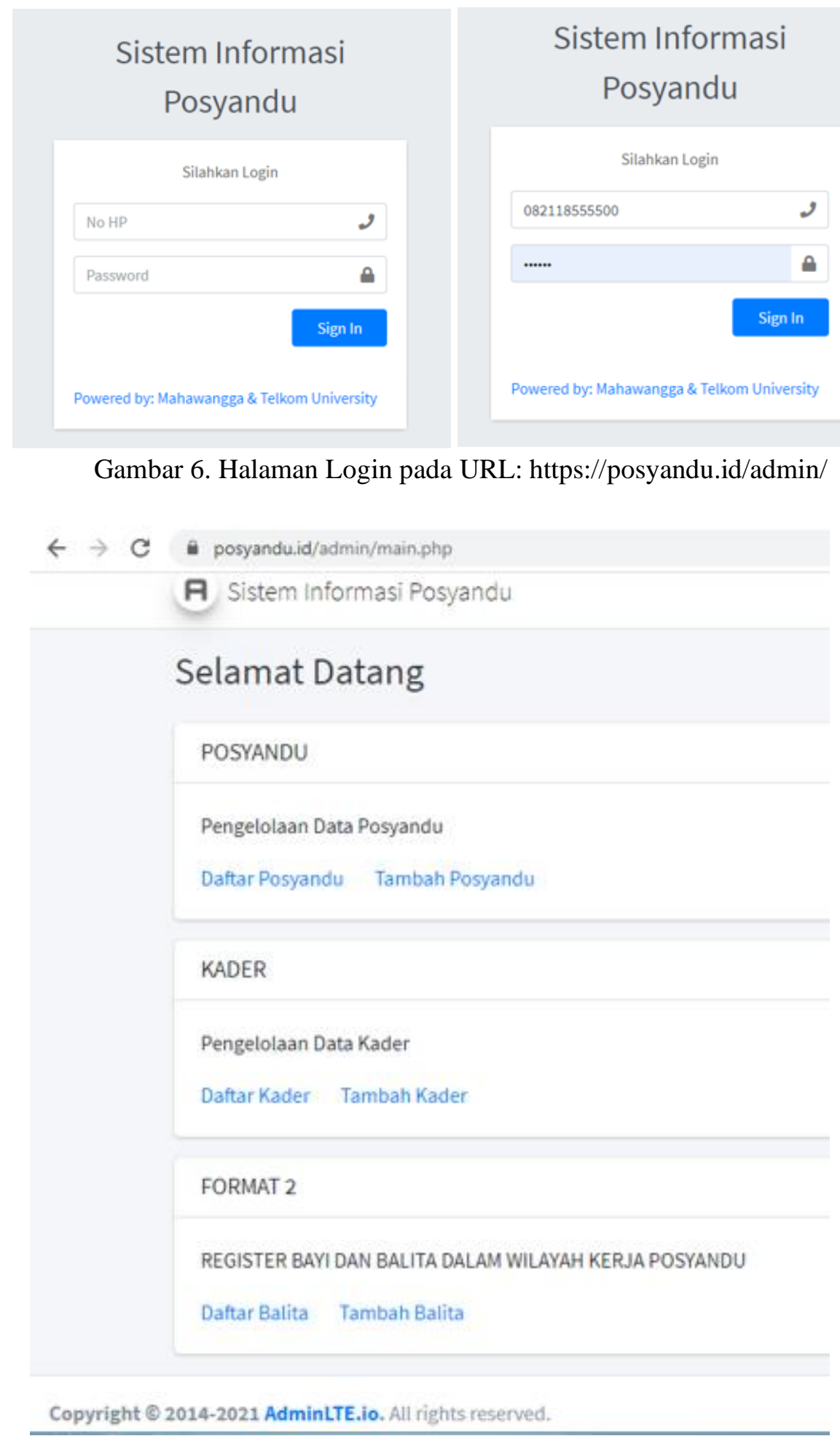

Gambar 7. Halaman depan selamat datang. 


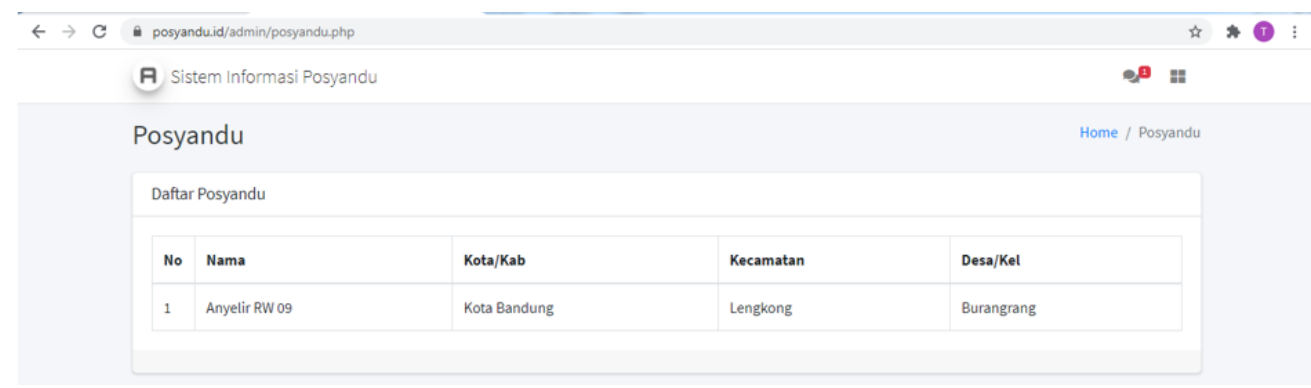

Gambar 8. Halaman daftar posyandu.

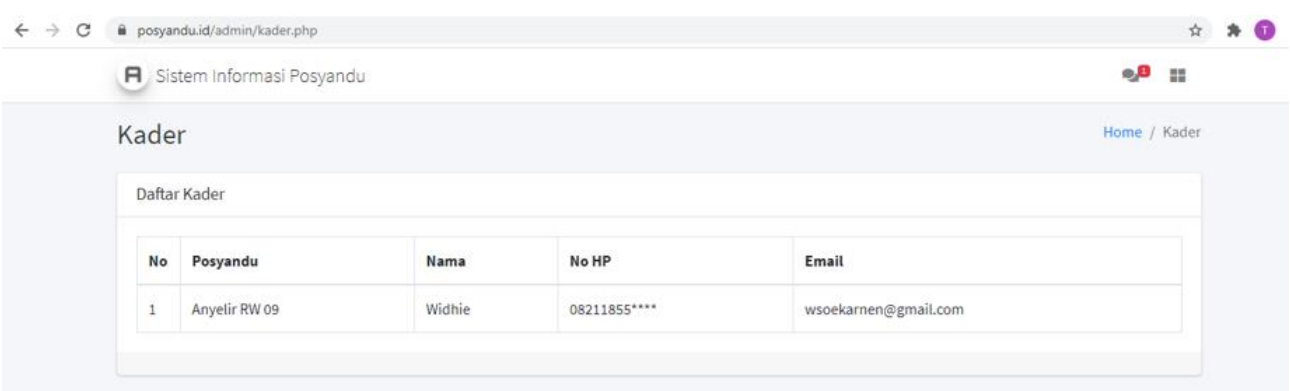

Gambar 9. Halaman daftar kader

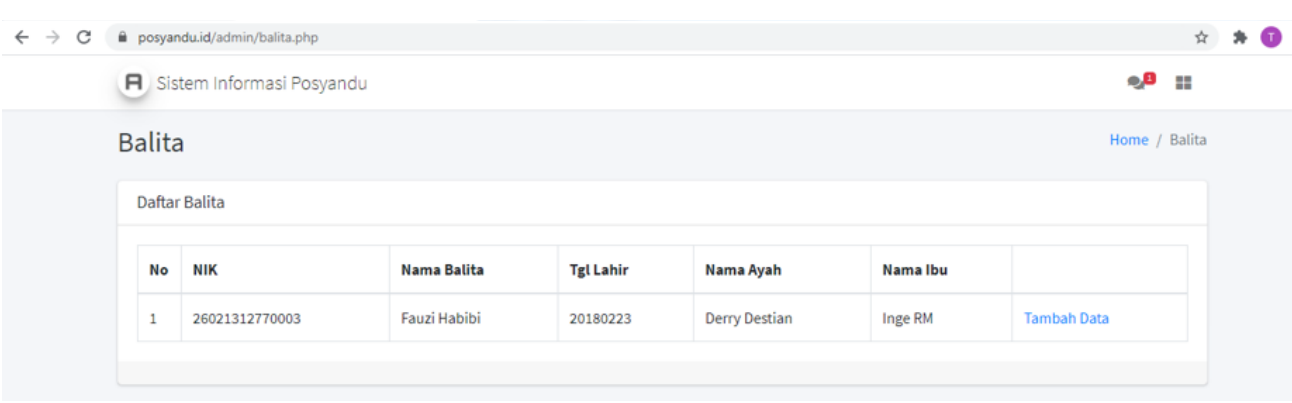

Gambar 10. Halaman daftar balita

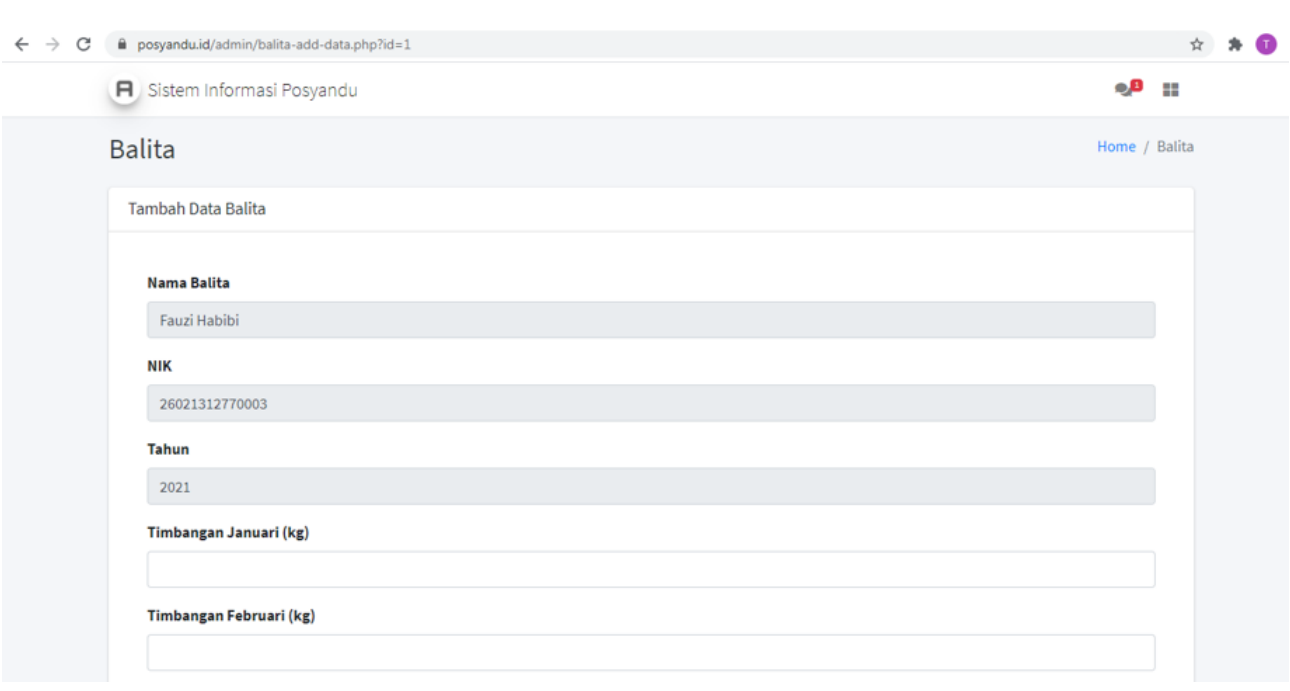




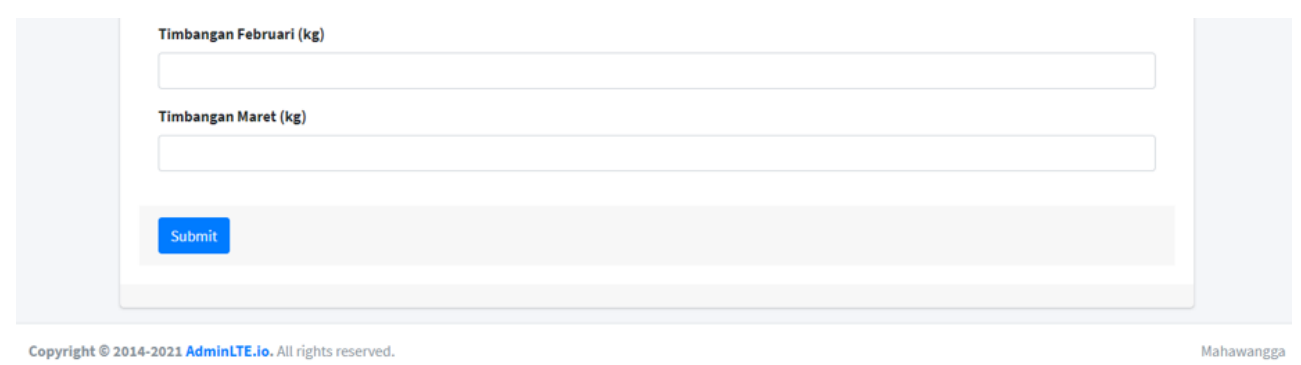

Gambar 11. Halaman tambah data balita

Kegiatan pembuatan dan pengujian program di satu posyandu yang telah ditetapkan, yaitu di Posyandu Anyelir 09 Kelurahan Burangrang Kecamatan Lengkong Kota Bandung, sebagai contoh input data posyandu, data kader, dan data balita telah berhasil dilakukan. Pelatihan program digitalisasi berupa kegiatan pembuatan panduan pelatihan digitalisasi pengisian data peserta posyandu dan pengumpulan data untuk keperluan pemantauan dinas kesehatan di posyandu kota bandung, belum dapat dilaksanakan. Demikian juga dengan pembuatan video seluruh kegiatan pengabdian masyarakat berupa pelatihan program kepada kader akan dilaksanakan dalam bulan Februari 2021 ini.

\section{Kesimpulan dan Saran}

Pengabdian Masyarakat ini bermitra dengan PT Mahawangga Winaya Indonesia untuk digitalisasi pengisian data peserta posyandu dan pengumpulan data untuk keperluan pemantauan dinas kesehatan di posyandu kota bandung, Pengabdian ini terdiri dari tiga kegiatan yang bersinambungan, yaitu pembuatan program, pengujian program, dan pelatihan program. Kegiatan pembuatan dan pengujian program telah dapat dilaksanakan. Namun untuk kegiatan selanjutnya, yaitu kegiatan pelatihan belum dapat dilaksanakan.

\section{DAFTAR PUSTAKA}

[1] Salinan Permendagri 19 tahun 2011. https://peraturan.bkpm.go.id/jdih/userfiles/batang/Permendagri_19_2011.pdf

[2] Peraturan Bupati Bandung Nomor 32 Tahun 2016 Tentang Rivitalisasi Posyandu. https://www.bandungkab.go.id/uploads/20170428074111-perbup-32-tahun-2016-revitalisasiposyandu.pdf

[3] Top 99 Iovasi Pelayanan Publik Indonesia 2017, Kementerian Pendayagunaan Aparatur Negara dan Reformasi Birokrasi. https://www.scribd.com/document/441709462/2017-Buku-TOP-992017-1-pdf 
[4] Iwan Awaludin, Nurjanah Syakrani, Eddy Bambang Soewono, Inovasi Dan Data Elektronik Untuk Posyandu Kelurahan Caringin Kota Bandung, IKRAITH-ABDIMAS Vol 2 No 2 Bulan Juli 2019.

[5] Encang Saepudin, Edwin Rizal, Agus Rusman, Peran Posyandu Sebagai Pusat Informasi Kesehatan Ibu dan Anak, RECORD AND LIBRARY JOURNAL, Volume 3, Nomor 2, JuliDesember 2017.

[6] Hetty Maria Isabela Sihotang, Nursiti Rahma, Faktor Penyebab Penurunan Kunjungan Bayi Di Posyandu Puskesmas Langsat Pekanbaru Tahun 2016, Journal Endurance 2(2) June 2017 (168177).

[7] Etih Henriyani dan Ahmad Juliarso, Revitalisasi Posyandu : Inovasi Pelayanan Kesehatan Di Kota Banjar, Prosiding Seminar Nasional: Kebijakan Dan Perencanaan Kota Berwawasan Kesehatan, http://digilib.mercubuana.ac.id/manager/t!@file_artikel_abstrak/Isi_Artikel_425030982793.pdf

[8] Profil Kesehatan Provinsi Jawa Barat Tahun 2016, Dinas Kesehatan Propinsi Jawa Barat. http://diskes.jabarprov.go.id/dmdocuments/9738b8d46840cc981f23c771c4187b6d.pdf

[9] Annisa Syafarani Callista, Ahmad Musnansyah, Widianto Soekarnen, Laporan Kerja Praktek: Perancangan Sistem Informasi Pelayanan Posyandu Kota Bandung Berbasis Aplikasi Web Di PT. Mahawangga Winaya Indonesia, Program Studi Sistem Informasi, Fakultas Rekayasa Industri, Universitas Telkom, 2020.

[10] Angelina Ervina Jeanette Egeten, Siska A. Damanik, Ika Agustina, Marcelina Panggabean, Perancangan Sistem Informasi Posyandu Berbasis Web Pada Yayasan Kalyana Mitra Di Jakarta Timur Untuk Mendukung Program Bidang Pendampingan Komunitas, Jurnal MATRIK, Vol.18 No.2 (Mei) 2019, Hal 330-338.

[11] Sri Widaningsih, Fitri Kurnia Efendi, Sistem Pelayanan Posyandu Berbasis Web Sebagai Sarana dalam Meningkatkan Kesehatan Ibu dan Anak Di Posyandu Sartika Cikondang, Media Jurnal Informatika, Vol. 10, no.2, Desember 2018.

[12] Yustina Meisella Kristania, Firda Dini Yulianti, Perancangan Sistem Informasi Pelayanan Pada Posyandu Pepaya Purwokerto, Jurnal Evolusi Volume 7 No 1 - 2019.

[13] Sri Kusumadewi, Rahadian Kurniawan, Hepi Wahyuningsih, Implementasi Sistem Informasi Posyandu Berbasis Web Dan Android Di Desa Bimomartani, Jurnal Pengabdian Dan Pemberdayaan Masyarakat, Volume 3 No. 2 September 2019.

[14] Ika Ratna Indra Astutik, Hana Catur Wahyuni, Sri Mukhodim Hanum, Peningkatan Kualitas Pelayanan Posyandu Balita Berbasis Sistem Informasi, Prosiding Semnas PPM 2017, UNESA 2017.

[15] Ryma Hermawaty, Ii Supiandi, Sistem Informasi Untuk Pelayanan Posyandu Berbasis Web dan Menggunakan Fitur SMS Gateway, Prosiding The 11th Industrial Research Workshop and National Seminar, Bandung, 26-27 Agustus 2020. 